\title{
Renata Seweryn
}

Uniwersytet Ekonomiczny w Krakowie

Wydział Zarządzania

e-mail: renata.seweryn@uke.krakow.pl

\section{Pokolenie Baby Boomers na rynku turystycznym na przykładzie odwiedzających Kraków}

Kody JEL: D12, L83, Z33

Słowa kluczowe: generacja, Baby Boomers, turystyka, zachowania

Streszczenie. Celem artykułu jest odpowiedź na pytanie, czy Baby Boomers są specyficzną grupą konsumentów na rynku turystycznym, a jeśli tak, to w których aspektach. Bazując na informacjach pochodzących z badań ruchu turystycznego w Krakowie, przeprowadzonych w 2016 roku, określono (za pomocą testu U Manna-Whitneya i testu $\chi^{2}$ Pearsona) statystycznie istotne różnice w zachowaniach turystycznych przedstawicieli tej generacji w porównaniu z innymi turystami. Uzyskane wyniki pozwalają stwierdzić, że dla Baby Boomers charakterystyczne są: katalogi i przewodniki jako źródła informacji, poznawcze i wypoczynkowe motywy wyjazdów z rodziną i ewentualnie przyjaciółmi, zakup weekendowych lub tygodniowych pakietów w biurze podróży oraz korzystanie $\mathrm{z}$ autokaru i samolotu oraz hotelu.

\section{Wprowadzenie}

W ujęciu naukowym pojęcie, ,pokolenie” pojawiło się niedawno. Początkowo termin ten służył do określenia grupy ludzi urodzonych w określonym czasie. Współczesna definicja słownikowa uwzględnia już zarówno aspekt czasowy, jak i jakościowy. Określa się w niej, że pokolenie to wyodrębniony z populacji zbiór osób, które nie tylko żyją w zbliżonym do siebie okresie, ale także mają wspólne doświadczenia (tzw. przeżycia pokoleniowe) i perspektywy życiowe (Karmolińska-Jagodzik, 2012, s. 191-193). Członkowie danej generacji dzielą zatem takie 
samo społeczne, ekonomiczne, polityczne i historyczne środowisko - „podróżują przez życie", doświadczając w podobnym wieku podobnych wydarzeń (Williams, Page, 2011, s. 2). Dzięki temu charakteryzują się zbliżoną mentalnością, poglądami, uznawanymi wartościami, aspiracjami, stylem życia i wzorcami postępowania (Hoffner, 2012, s. 1084).

Na współczesnym rynku można wyróżnić kilka pokoleń konsumentów. Najczęściej wskazywane są (Borges, Manuel, Elam, Jones, 2010; Pendergast, 2010):

1. Tradycjonaliści (nazywani również m.in. Weteranami, Silent Generation, Radio Babies - urodzeni przed 1946 r.).

2. Baby Boomers (inaczej: Me Generation, Baboo, Love Generation, Woodstock lub Sandwich Generation - urodzeni w latach 1946-1964).

3. X (określane także m.in. jako Post Boomers, Baby Busters, Slackers, pokolenie widmo, pokolenie stracone - urodzeni w okresie 1965-1980).

4. Y (znane też jako Millennials, Echo Boomers, Gen Wired, DotNet, First Globals, iPod Generation - urodzeni w latach 1981-1994).

5. Z (nazywane też m.in. Internet lub Google Generation, pokolenie „kopiujwklej”, pokolenie „kciuka” bądź „,sieciaki” - urodzeni po 1994 r.).

$\mathrm{W}$ artykule uwagę skoncentrowano na drugim $\mathrm{z}$ wymienionych pokoleń, $\mathrm{tj}$. Baby Boomers. Celem opracowania jest próba odpowiedzi na pytanie, czy członkowie tej generacji są specyficzną grupą konsumentów na rynku turystycznym, a jeśli tak, to w których aspektach? Opierając się na informacjach pochodzących z badań ruchu turystycznego w Krakowie w 2016 roku, zidentyfikowano (za pomocą testu $\chi^{2}$ Pearsona i U Manna-Whitneya) różnice w zachowaniach turystycznych Baboo w porównaniu z innymi turystami. Najpierw jednak ukazano specyfikę tego pokolenia i dokonano zestawienia jego cech z właściwościami innych współczesnych kohort.

\section{Cechy charakterystyczne pokolenia Boomersów}

Największe pokolenie w historii ludzkości, tj. Baby Boomers, tworzą osoby urodzone wskutek wyżu demograficznego, który miał miejsce zaraz po zakończeniu II wojny światowej. Pod względem cech charakteryzujących styl życia przedstawiciele tego pokolenia są ambitni i dużą wagę przykładają do kariery, co znajduje odbicie w pracoholizmie (Hawkins, Mothersbaugh, 2016, s. 120-121). Wielu kontynuuje lub planuje kontynuować pracę podczas emerytury i chce pozostać aktywnymi. Boomersi uczą się nowych technologii, a około $1 / 3$ z nich korzysta nawet z mediów społecznościowych.

Zdrowie, energia i dobre samopoczucie stanowią dla Boomersów istotne cele, dlatego koncentrują się oni na zatrzymaniu młodości i spowolnieniu przyrostu masy ciała. Nie chcą, aby przypominano im o starzeniu się, podejmują działania i zabiegi anty aging, przełamując stereotypy na temat osób 50+ (Court, Far- 
rell, Forsyth, 2007, s. 109-110). Coraz częściej, szczególnie osoby samotne, korzystają również z usług gastronomicznych, nie tylko w celu zaspokojenia głodu, ale również ze względu na poszukiwanie towarzystwa i zagospodarowanie czasu wolnego. Rozwój systemów zabezpieczeń na starość (m.in. funduszy emerytalnych) sprawił, że w krajach rozwiniętych Boomersi mają coraz więcej pieniędzy do wydania. Dotychczasowy wizerunek osoby starszej jako jednostki biednej ustępuje więc obrazowi aktywnego, zainteresowanego życiem człowieka i konsumenta, który swoje wysublimowane potrzeby chce zaspokajać wieloma dobrami i usługami (Bylok, 2013, s. 124-130). Mimo że Baboo dysponują znacznymi dochodami i oszczędnościami, to są bardzo wrażliwi na cenę.

\section{Baby Boomers w porównaniu z przedstawicielami innych generacji}

Jedną z cech różnicujących współczesne pokolenia jest stopień wykorzystania IT. Otóż dla Boomersów nowinki techniczne są wprawdzie bardziej zrozumiałe niż dla poprzedniej generacji (Rosenberg, 2008, s. 41-44), ale pierwszym pokoleniem regularnie korzystającym z nowych technologii są Iksy (Eisner, 2005, s. 416). Przedstawiciele generacji $Y$ dorastali już z internetem, wręcz wychowali się na smartfonach, portalach społecznościowych itp., stąd funkcjonują w elektronicznej i wirtualnej społeczności (Crampton, Hodge, 2009, s. 3), aczkolwiek jeszcze bardziej dotyczy to pokolenia Z.

Pod względem stylu życia i oczekiwań, w przeciwieństwie do raczej konserwatywnych, altruistycznych i oszczędnych Tradycjonalistów, Baby Boomers są podejrzliwi wobec władzy i autorytetów, egocentryczni, nastawieni na indywidualizm, „bycie tutaj, teraz”, ale przy tym rozważni i, jak już wspomniano, wrażliwi na cenę (Zajadacz, 2014, s. 58-59). Z kolei priorytetem życiowym pokolenia $X$ jest autonomia i pragmatyczność. Charakteryzuje ich samowystarczalność, zdolność do rozwiązywania wszelkich zadań i przeciwności losu. Iksy są też bardzo świadomymi nabywcami na rynku, przywiązującymi dużą wagę nie tylko, jak Baboo, do cen produktów, ale również do ich jakości (Armstrong, Kotler, 2016, s. 128-129). Niezależność cenią sobie także Ygreki, które na dodatek są przyzwyczajone do różnorodności świata i dobrze odnajdują się w środowisku multikulturowym (Fazlagić, 2008, s. 13). Są to osoby ciekawe doznań, odkrywania nowych dróg i możliwości oraz skłonne do spontanicznych decyzji. Jeszcze bardziej otwarci i gotowi do przyjmowania liberalnych wartości okazują się reprezentanci generacji Z. Ponadto są to jednostki bardzo pomysłowe i innowacyjne. Charakteryzuje je też pewność siebie i oczekiwanie natychmiastowej gratyfikacji (Wiliams, Page, 2010, s. 10).

O ile Tradycjonaliści prowadzą raczej osiadły styl życia, związany z częstym oglądaniem telewizji, słuchaniem radia i czytaniem gazet, to Boomersi relatywnie częściej podróżują, zwłaszcza w celach zdrowotnych i spowolnienia 
procesów starzenia, ceniąc sobie przy tym dogodną lokalizację, kompetentną obsługę i niskie ceny (Zajadacz, 2014, s. 59). Jeszcze aktywniejsi turystycznie są przedstawiciele pokolenia $\mathrm{X}$, ale najbardziej podróżami interesują się Ygreki (Pendergast, 2010, s. 1-15), którzy na dodatek są w stanie, jako osoby przyzwyczajone do zasięgania informacji z sieci, samodzielnie je sobie zorganizować (Seweryn, Niemczyk, 2015, s. 79).

Na podstawie zaprezentowanych wyróżników pokolenia Baby Boomers można wnioskować, że są oni specyficzną grupą konsumentów, także na rynku turystycznym. Tezę tę postanowiono zweryfikować empirycznie.

\section{Metodyka badań}

Dla znalezienia odpowiedzi na pytanie, czy w ogóle i czym wyróżniają się zachowania turystyczne Baby Boomers, wykorzystano wyniki badań ruchu turystycznego, przeprowadzone w Krakowie w 2016 roku na zlecenie Urzędu Miasta pod nadzorem Małopolskiej Organizacji Turystycznej. Kwestionariusz wypełniło wówczas 3501 respondentów (Borkowski, Grabiński, Seweryn, Mazanek, Grabińska, 2017, s. 5-8), ale na potrzeby niniejszego artykułu wykorzystano odpowiedzi 3368 badanych, w tym 603 Boomersów. Statystycznie istotne różnice między reprezentantami tego pokolenia a innymi odwiedzającymi miasto określono za pomocą testu $\chi^{2}$ Pearsona (w odniesieniu do cech wyrażonych $w$ skali nominalnej) i U Manna-Whitneya (w przypadku zmiennych wyrażonych w skali porządkowej). Postawiono 20 razy dwie hipotezy statystyczne: $\mathrm{H}_{0}$ - zachowania przedstawicieli pokolenia Baby Boomers były takie same, jak zachowania innych odwiedzających Kraków oraz $\mathrm{H}_{1}$ jako hipotezę alternatywną. W sytuacji gdy wynik prawdopodobieństwa testowego $p$ był mniejszy od $\alpha=0,05$, należało przyjąć $H_{1}$. $\mathrm{W}$ przeciwnym wypadku nie było podstaw do odrzucenia $\mathrm{H}_{0}$. Uzyskane wyniki zaprezentowano w tabeli 1.

Tabela 1

Wyniki testów istotności różnic w zachowaniach turystycznych Baby Boomers i innych odwiedzających Kraków w 2016 r.

\begin{tabular}{|c|c|c|c|}
\hline & Zmienne & Test & $p^{*}$ \\
\hline Prasa & \multirow{11}{*}{$\begin{array}{l}\text { jako źródło informacji } \\
\text { o Krakowie }\end{array}$} & \multirow{11}{*}{$\begin{array}{l}\chi^{2} \text { z po- } \\
\text { prawką } \\
\text { Yatesa }\end{array}$} & $p=0,94628$ \\
\hline Radio & & & $p=0,10191$ \\
\hline Telewizja & & & $p=0,05910$ \\
\hline Internet & & & $p=0,00026$ \\
\hline Social media & & & $p=0,00000$ \\
\hline Przewodniki & & & $p=0,00895$ \\
\hline Katalogi biur podróży & & & $p=0,00000$ \\
\hline Foldery i ulotki & & & $p=0,85614$ \\
\hline Rodzina & & & $p=0,00000$ \\
\hline Znajomi & & & $p=0,02944$ \\
\hline Szkoła & & & $p=0,00000$ \\
\hline
\end{tabular}




\begin{tabular}{|c|c|c|}
\hline Korzystanie z usług przewodników w Krakowie & & $p=0,11417$ \\
\hline Korzystanie z informacji turystycznej w Krakowie & & $p=0,41090$ \\
\hline Główny motyw przyjazdu do Krakowa & \multirow{5}{*}{$\chi^{2}$} & $p=0,00000$ \\
\hline Organizator podróży do Krakowa & & $p=0,00000$ \\
\hline Towarzystwo w podróży do Krakowa & & $p=0,00000$ \\
\hline Środek transportu wykorzystywany w podróży do Krakowa & & $p=0,00000$ \\
\hline Miejsce noclegu w Krakowie & & $p=0,00000$ \\
\hline Długość pobytu w Krakowie & \multirow{2}{*}{$\begin{array}{l}\text { U Manna- } \\
\text { Whitneya }\end{array}$} & $p=0,00062$ \\
\hline Przeciętne wydatki podczas pobytu w Krakowie & & $p=0,00000$ \\
\hline
\end{tabular}

* Pogrubieniem zaznaczono różnice statystycznie istotne.

Źródło: obliczenia własne.

Przedstawione wyniki pozwalają stwierdzić, że nie występują statystycznie istotne odmienności między reprezentantami pokolenia Baboo i innymi odwiedzającymi Kraków, jeśli chodzi o korzystanie z tradycyjnych mediów oraz folderów i ulotek jako źródeł informacji o mieście, a także z usług przewodnickich i informacji turystycznej. Pozostałe aspekty zachowań konsumenckich istotnie różnicują między sobą te dwie grupy turystów.

\section{Specyfika zachowań rynkowych w turystyce Baby Boomers}

Jedną ze zmiennych istotnie wyróżniających zachowania konsumenckie w turystyce przedstawicieli Baby Boomers jest źródło informacji o destynacji. Można zauważyć, że Baboo częściej korzystają (rys. 1) ze źródeł pisanych, czyli katalogów biur podróży (ponad dwukrotnie więcej wskazań) oraz przewodników (prawie 1,5-krotnie).

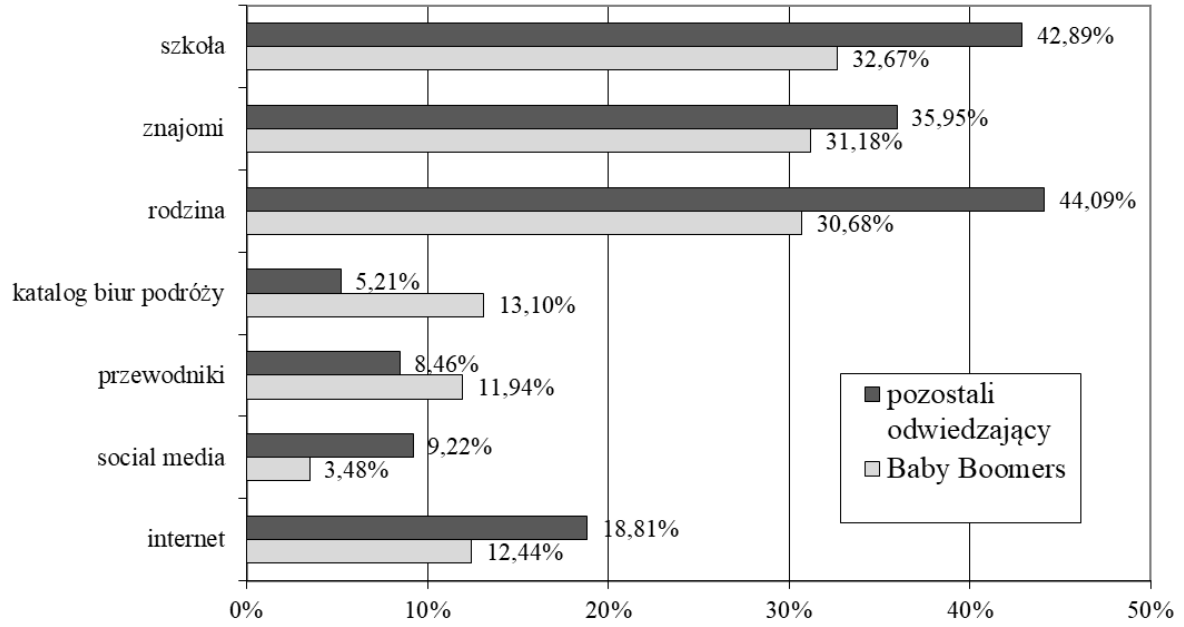

Rysunek 1. Źródła informacji o Krakowie wykorzystywane przez Baby Boomers i innych odwiedzających miasto w 2016 roku

Źródło: opracowanie własne. 
Z kolei pozostali odwiedzający Kraków w większym stopniu, co wydaje się oczywiste, biorąc pod uwagę, że są to osoby z reguły młodsze od Boomersów, preferują nowoczesne technologie (internet i media społecznościowe) oraz informacje przekazywane w ramach tzw. promocji szeptanej. Częściej też słyszeli o dawnej stolicy Polski ze szkoły.

Inną cechą istotnie wyróżniającą przedstawicieli Baby Boomers jest motyw podróży turystycznej. Wprawdzie w obu grupach odwiedzających Kraków dominuje zwiedzanie zabytków, ale częściej (o ponad 56\%) jest ono wskazywane przez Boomersów. Przedstawiciele tej generacji w minimalnie większym odsetku przyjeżdżają do miasta również w celach wypoczynkowych (rys. 2). Inni odwiedzający przeważają natomiast $w$ odniesieniu do tak oczywistych dla tych generacji (ze względu na ich młodszy wiek) motywów podróży, jak: rozrywkowy, towarzyski i biznesowy, aczkolwiek częściej w 2016 roku wskazywali oni też cel religijny (z uwagi na Światowe Dni Młodzieży) i tranzytowy.

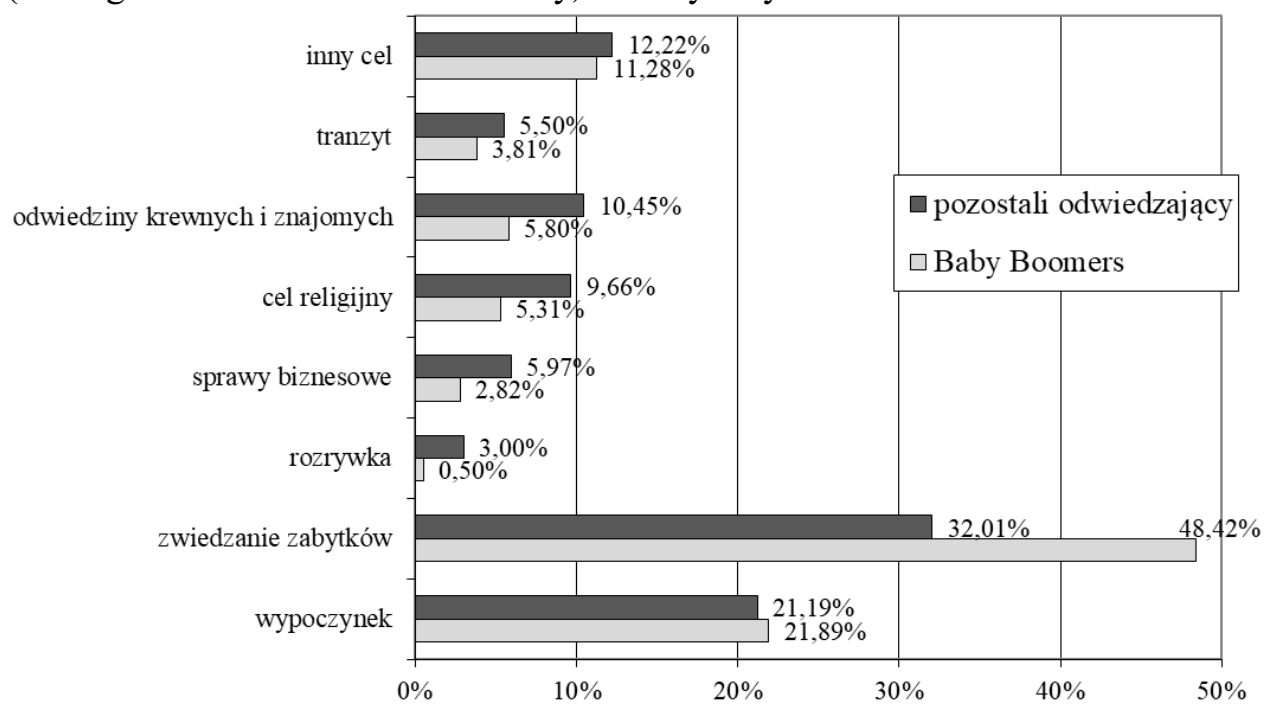

Rysunek 2. Główny motyw przyjazdu do Krakowa Baby Boomers i innych odwiedzających miasto w 2016 roku

Źródło: opracowanie własne.

Analizując kwestię organizatora podróży, należy stwierdzić, że do Krakowa odwiedzający przyjeżdżają z reguły samodzielnie, przy czym większy odsetek (o 7,5 p.p.) przedstawicieli innych generacji niż Baboo deklaruje tego typu zachowania turystyczne, podobnie organizację przyjazdu przez zakład pracy (prawie trzykrotnie), rodzinę (ponad dwukrotnie) i znajomych, parafię/kościół i tzw. inną instytucję (rys. 3). Reprezentanci Baby Boomers przeważają natomiast w przypadku korzystania z usług biur podróży (ponad czterokrotnie więcej wskazań). 
Wynika to przypuszczalnie z faktu, że przedstawiciele tej generacji byli i są przyzwyczajeni do tej formy organizacji wyjazdów turystycznych, a ponadto, skoro nie są tak sprawni w korzystaniu z IT, jak ich następcy, biuro podróży jest dla nich istotnym podmiotem, w którym mogą dokonać wyboru i zakupu oferty. Potwierdzają się jednocześnie wcześniejsze wyniki odnośnie do katalogów jako źródła informacji o destynacji.

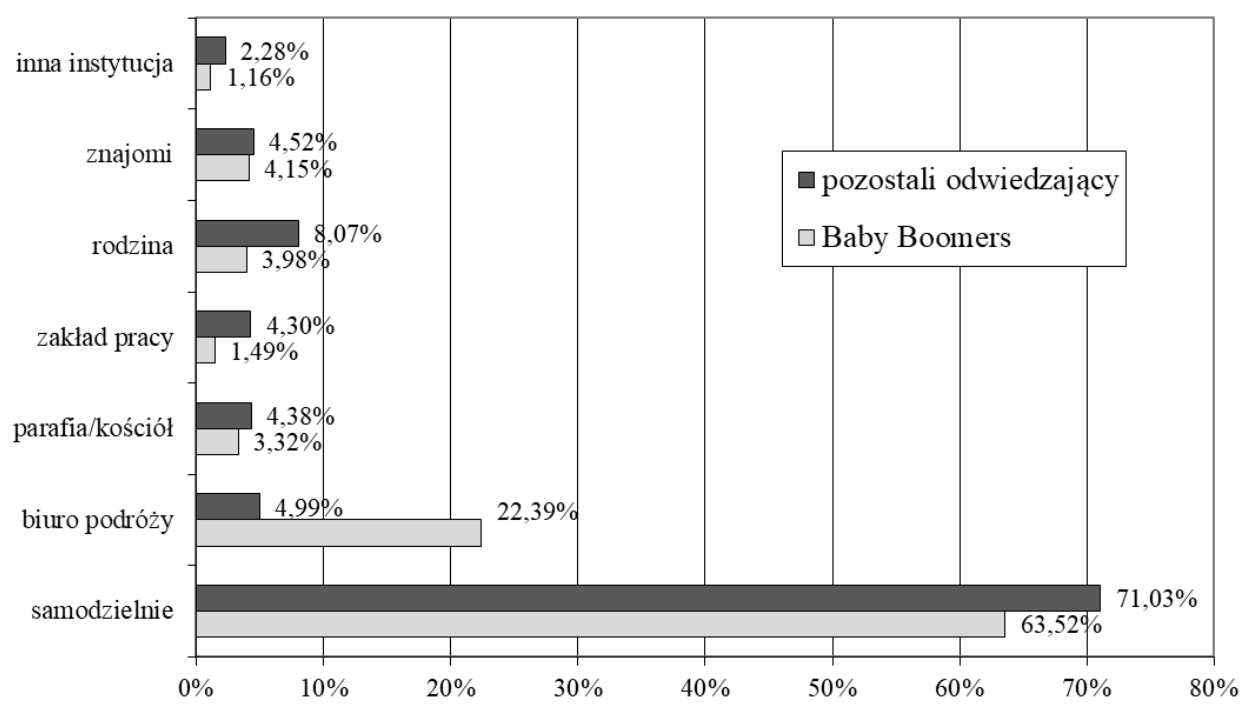

Rysunek 3. Organizator podróży do Krakowa Baby Boomers i innych odwiedzających miasto w 2016 roku

Źródło: opracowanie własne.

Towarzystwo w podróży również istotnie identyfikuje zachowania turystyczne Baby Boomers oraz pozytywnie weryfikuje poprzednie ustalenia. Mianowicie Baboo częściej (ponad dwukrotnie) przyjeżdżają do Krakowa $\mathrm{z}$ grupą zorganizowaną. W większym stopniu niż inni odwiedzający miasto podróżują też $\mathrm{z}$ rodziną (prawie o $45 \%$ więcej wskazań) oraz $\mathrm{z}$ rodziną i przyjaciółmi (niemal o 1/3). Z kolei wyższemu odsetkowi (ponad trzykrotnie) przedstawicieli pozostałych generacji towarzyszą przyjaciele (rys. 4).

Rozpatrując długości pobytu, należy stwierdzić, że Boomersów charakteryzuje przebywanie w Krakowie od trzech dni do tygodnia (w sumie prawie $71 \%$ w porównaniu do ponad 54\% wskazań). Zarówno krótsze, jak i dłuższe pobyty (w tym zwłaszcza powyżej dwóch tygodni) cechują natomiast innych odwiedzających miasto (rys. 5). 


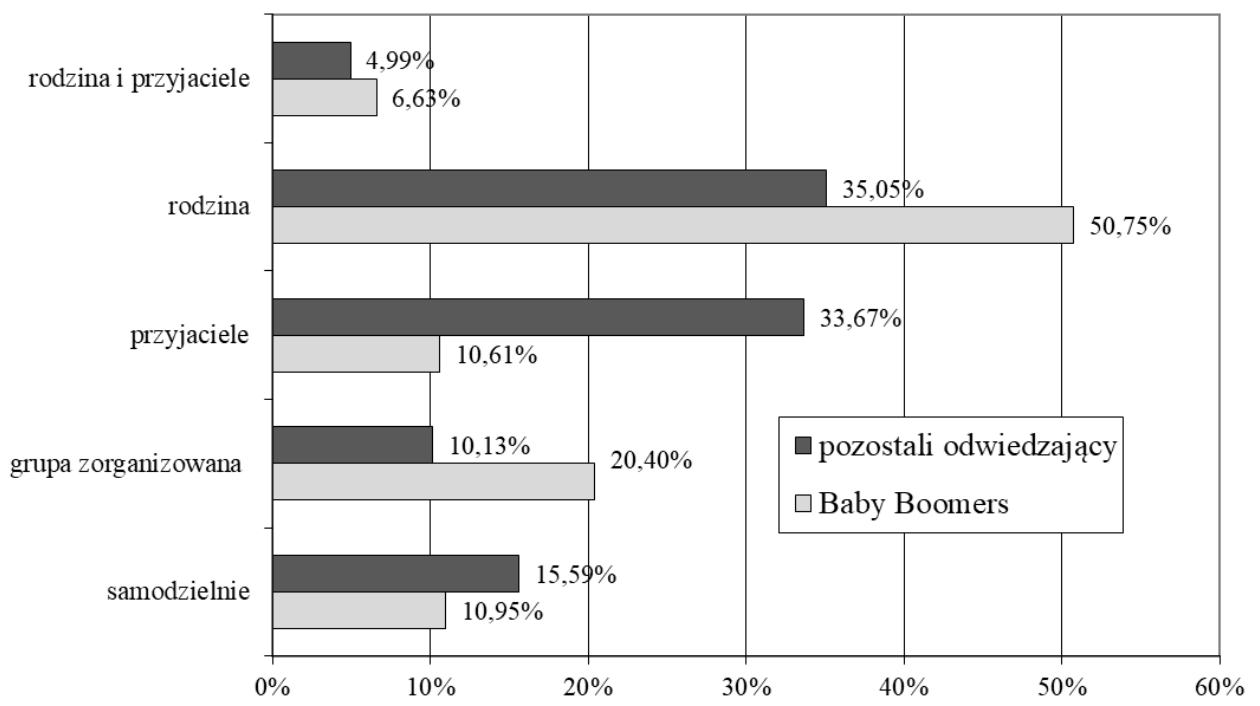

Rysunek 4. Towarzystwo w podróży do Krakowa Baby Boomers i innych odwiedzających miasto w 2016 roku

Źródło: opracowanie własne.

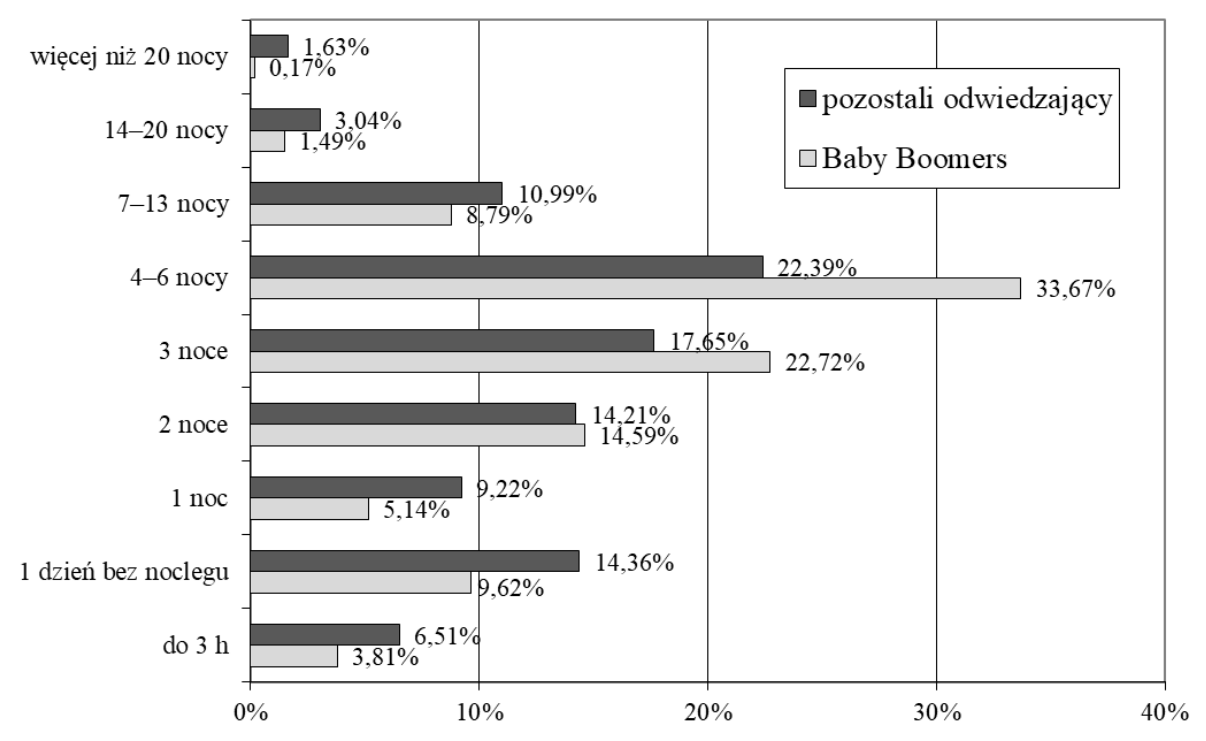

Rysunek 5. Długość pobytu w Krakowie Baby Boomers i innych odwiedzających miasto w 2016 roku

Źródło: opracowanie własne. 
Jeśli chodzi o środek transportu preferowany w trakcie podróży turystycznej do Krakowa, to, jak wynika z danych na rysunku 6, reprezentanci pokolenia Baby Boomers w większym odsetku korzystają z autokaru i samolotu (odpowiednio o ponad 55\% i w sumie o niemal 70\% wskazań więcej). Z kolei pozostali odwiedzający miasto częściej wybierają tańsze środki lokomocji, tj. autobus linii regularnej (ponad 2,5-krotnie), pociąg i tzw. inny środek transportu (prawie dwukrotnie), a także minimalnie samochód (o 2,3\% wskazań więcej).

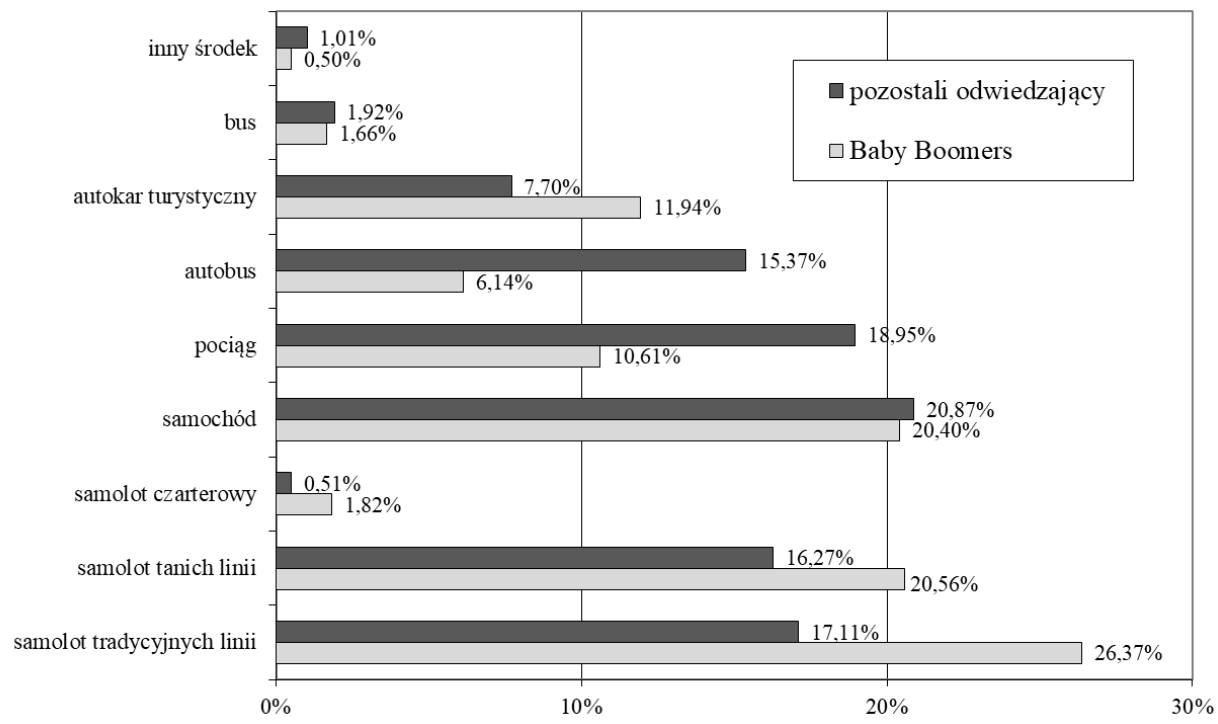

Rysunek 6. Środki transportu wykorzystywane w podróży do Krakowa przez Baby Boomers i innych odwiedzających miasto w 2016 roku

Źródło: opracowanie własne.

Tańsze miejsca zakwaterowania również częściej wskazywane są przez młodszych niż Baby Boomers odwiedzających miasto (rys. 7). Większy ich odsetek nocuje bowiem u znajomych (ponad 5,5-krotnie), w hostelach (prawie trzykrotnie), w obiektach hotelarskich innych niż hotele (prawie 1,5-krotnie), apartamentach/kwaterach prywatnych (o prawie 5\%) i innych obiektach (o 58\%). Baboo częściej natomiast wybierają hotele (ponaddwukrotnie) i nocleg u rodziny (o ok. 9\% więcej wskazań).

Ostatnim z wyróżników Baboo jest wysokość wydatków podczas pobytu w Krakowie - mianowicie pozostawiają oni w mieście kwoty większe niż pozostali odwiedzający (rys. 8). 


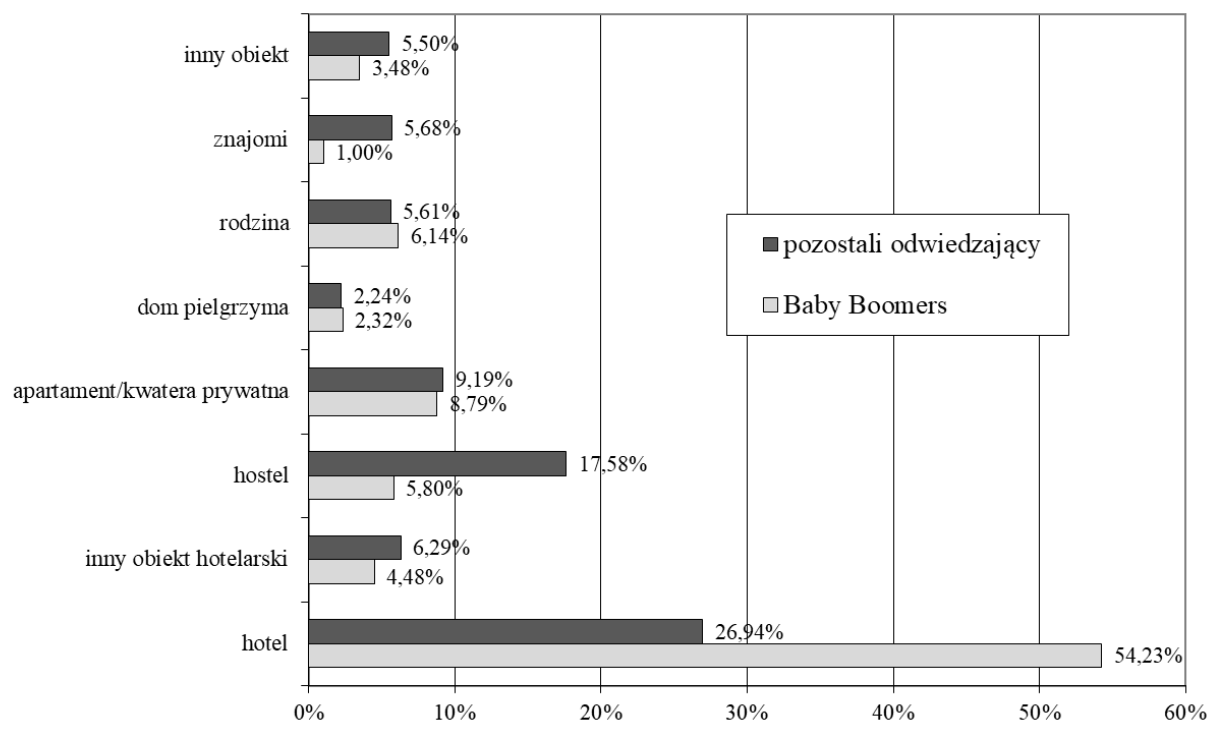

Rysunek 7. Miejsce noclegu w Krakowie Baby Boomers i innych odwiedzających miasto w 2016 roku

Źródło: opracowanie własne.

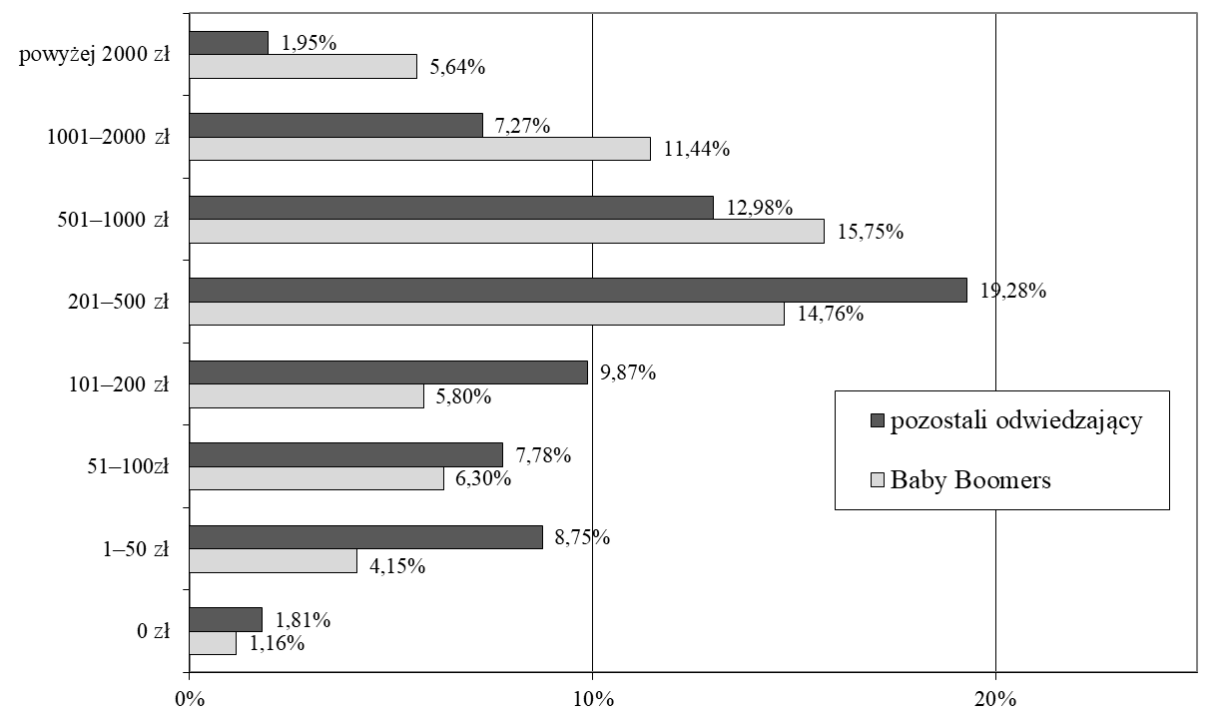

Rysunek 8. Wydatki w Krakowie Baby Boomers i innych odwiedzających miasto w 2016 roku

Źródło: opracowanie własne. 
Sumy powyżej 500 zł są bowiem charakterystyczne dla większego odsetka Baby Boomers (w sumie prawie 1,5-krotnie więcej wskazań), a niższe - dla przedstawicieli innych pokoleń turystów.

\section{Podsumowanie}

W dobie globalizacji, a tym samym światowej konkurencji, klasyfikacja nabywców, biorąc pod uwagę kryterium wieku, jest często wykorzystywana w segmentacji rynku turystycznego, gdzie podstawowym pytaniem jest: „dla kogo przygotowana ma być oferta?". Informacjami niezbędnymi w działaniach marketingowych firm są zatem te dotyczące wyróżników poszczególnych grup wiekowych (pokoleniowych). Przeprowadzone analizy pozwalają stwierdzić, że w stosunku do osób z generacji Baby Boomers, które w momencie pisania niniejszego artykułu mają w granicach 53-71 lat, czyli w dużej mierze są najstarszymi podróżującymi, mało skuteczna byłaby promocja i dystrybucja za pośrednictwem internetu i social mediów. Reprezentanci tego pokolenia w niewielkim bowiem zakresie korzystają z IT, preferując tradycyjne kanały dystrybucji, czyli biura podróży. Te ostatnie powinny zatem przygotować dla tej grupy (i dla towarzyszących im rodzin) ,szyty na miarę" produkt w postaci weekendowego lub tygodniowego pakietu, obejmującego przejazd autokarem lub przelot samolotem, zakwaterowanie w hotelu, zwiedzanie lub (i) wypoczynek. Cena tego pakietu nie musi być minimalna, gdyż pokolenie Baby Boomers charakteryzuje się relatywnie wysokimi wydatkami turystycznymi.

\section{Bibliografia}

Armstrong, G., Kotler, Ph. (2016). Principles of marketing. Harlow: Pearson Education Limited.

Borges, N., Manuel, R., Elam, C., Jones, B. (2010). Differences in motives between Millennial and Generation X medical Students. Medical Education, 44 (6), 570-576.

Borkowski, K., Grabiński, T., Seweryn, R., Mazanek, L., Grabińska, E. (2014). Ruch turystyczny w Krakowie w 2016 roku. Kraków: Małopolska Organizacja Turystyczna.

Bylok, F. (2013). Strategie zachowań konsumpcyjnych seniorów na rynku dóbr i usług konsumpcyjnych. Problemy Zarzadzania 11, 1 (40), t. 1, 123-142.

Court, D., Farrell, D., Forsyth, J.E. (2007). Serving aging Baby Boomers. The McKinsey Quarterly, 4, 103-113.

Crampton, S.M., Hodge, J.W. (2009). Generation Y: unchartered territory. Journal of Business \& Economics Research, 7 (4), 1-6.

Eisner, S.P. (2005). Managing generation Y. SAM Advanced Management Journal, 70 (4), 4-15.

Fazlagić, J.A. (2008). Charakterystyka pokolenia Y. E-mentor, 3 (25). Pobrano z: www.e-mentor.edu.pl/artykul/index/numer/25/id/549.

Hawkins, D.I., Mothersbaugh, D.L. (2016). Consumer behavior: Building marketing strategy. New York: McGraw-Hill Education.

Hoffner, M. (red.). (2012). Socjologia. Warszawa: Wydawnictwo Naukowe PWN.

Karmolińska-Jagodzik, E. (2012). Komunikacja międzypokoleniowa - rozważania wokół różnic kulturowych. Studia Edukacyjne, 21, 191-210. 
Pendergast, D. (2010). Getting to Know the Y Generation. W: P. Benckendorff, G. Moscardo, D. Pendergast (red.), Tourism and Generation Y. Cambridge: CAB International.

Rosenberg, J. (2008). Mind your generation. Journal of Property Management, 73 (6).

Seweryn, R., Niemczyk, A. (2015). Generations X and Y as Participants of Tourist Movement (by the Case of the Visitors to Krakow). Т. Дъбева (red.), Туризмъm в епохата на трансформация. Варна: Икономически Университет b Варна.

Williams, K.C., Page, R.A. (2011). Marketing to the Generations. Journal of Behavioral Studies in Business, 3 (1), 1-17.

Zajadacz, A. (2014). Pokolenie X, Y, Z a fenomen turystyki. W: J. Śledzińska, B. Włodarczyk (red.), Międzypokoleniowe aspekty turystyki. Warszawa: PTTK „Kraj”.

\section{Generation of Baby Boomers in the Tourism Market (on the Example of Tourists Visiting Kraków)}

Keywords: generation, Baby Boomers, tourism, behaviours

Summary. The purpose of the paper is to answer the question, whether Baby Boomers are the particular group of consumers in the tourism market; and if so, in which aspects. On the basis of the information coming from the research into tourist traffic in Kraków, conducted in 2016, there were established (using the Pearson chi-square test and MannWhitney $U$ test) the statistically significant differences of the tourist behaviors of the representatives of this generation compared with other tourists. The obtained results allows to conclude that characteristic for Baby Boomers are: catalogues and guidebooks as the sources of information, cognitive and relaxation motives for trip with the family and possibly with friends, buying weekend's or week's packages from the travel agency, using the coach or the plane and the hotel.

Translated by Renata Seweryn

\section{Cytowanie}

Seweryn, R. (2017). Pokolenie Baby Boomers na rynku turystycznym na przykładzie odwiedzających Kraków. Marketing i Zarządzanie, 2 (48), 105-116. DOI: 10.18276/miz.2017.48-10. 